\title{
EVOLUTION OF BEHAVIORAL ECONOMIC THEORY
}

\author{
I. Rezanovich, E. Rezanovich, A. Keller, I. Savelyeva \\ South Ural State University, Chelyabinsk, Russian Federation
}

\begin{abstract}
The emergence of behavioural economics is associated with desire of the economic theory to find an explanation for the existing paradoxes, which cannot be clarified from the standpoint of the classical economy. To solve this problem, achievements of other sciences and psychology are used.

Genesis of behavioural economics is presented in this article. The criterion for distinguishing the stages of its evolution is justified. The periodization has allowed defining influence of appearing theories on development of economic thought. The first stage (propaedeutic stage), directly connected with economic psychology, allowed authors to analyse the theory of expected utility and the theory of subjective expected utility from the psychological point of view. It revealed abnormal facts in the economic behaviour of individuals. The second stage (origin of behavioural economics) is closely connected to $A D y$ namic Theory of Personality by Kurt Lewin. Precisely at this stage the fundamental scientific schools were formed: a school of Carnegie Mellon University, which studies behaviour of companies in markets, and a Michigan School, which concentrated its attention on the behaviour of consumers. The third stage (formation of behavioural economics) integrated economic theory with cognitive psychology and mathematical psychology. It allowed explaining rational and irrational economic decision-making. The fourth stage (development of behavioural economics) is associated with the application of mathematical tools of game theory in economic theory, particularly in the sections that explain the strategic interaction of economic agents at different levels and in different conditions. The fifth stage (expansion of behavioural economics) is due to the influence of achievements in psychophysiology, neurophysiology, and neurobiology and makes it possible to create a new direction in the behavioural economics - neuroeconomics. The group of authors from South Ural State University is discovering new opportunities in the development of behavioural economics, using the advances in the study of human labour behaviour.

Keywords: behavioural economics, economic psychology, cognitive psychology, mathematical psychology, mathematical game theory, stages of development of behavioural economics, neuroeconomics, neuromanagement, modern perspective directions of research of behavioural economics.
\end{abstract}

\section{Introduction}

Currently, economics is developing quite dynamically, organically combining various theories, concepts, scientific schools and research fields that seek to reflect the transformations taking place in the surrounding world and give those explanations and find adequate recommendations for managing current situations. Undoubtedly, most of the classic scientific works of the last century are still considered relevant and are largely used in modern studies. But it should be recognized that for several last decades the positions of the "classics" (representatives of classical economy) are weakening. Empirical researches have led to the emergence of new theories explaining economic and managerial processes in spite of classical paradigms.

One of these theories is behavioural economics, which emerged from the penetration of various sciences, and, first of all, psychology, into the field of economic research. The formation of behavioural economic theory was thorny: the publication of each new study received both enthusiastic support and violent criticism. However, over the past half century this theory has gained more and more supporters and now represents several scientific schools that never cease to amaze the scientific community with new discoveries in the behaviour of consumers and firms.
The purpose of this article is to trace the evolution of the behavioural economics, to identify the stages of its formation and to identify some immediate prospects for further development.

While identifying the stages in the development of behavioural economic theory, authors will use the historical approach, according to which a basis for such work should be chosen. In our case, such a basis will be the relationship of the behavioural economics with different sciences.

Main stages of development of behavioural economics

The first stage (propaedeutic stage) is associated with the emergence of economic psychology (19401955). It should be noted that first prerequisites for economic psychology can be found in the works of A. Smith (Theory of Moral Senses) and J. Bentham (Utility Theory). However, with the emergence of the concept of "economic man" in the neoclassical economy, this relationship was lost. It began to revive only in the middle of the twentieth century. Basic scientific works were developed by G. Tarde [1] and L. Garai [2] (describing group consciousness), and works by G. Katona [3] (revealing the essence of the index of consumer preferences). Due to the described psychological patterns in the behaviour of a person and a group, it became possible to develop decision-making 


\section{Экономическая теория и мировая экономика}

concepts in conditions of insufficient information or uncertainty. In particular, the previously created economic models of "intertemporal utility" (intertemporal consumption in conditions of uncertainty) by I. Fisher [4] and "expected utility" by Neumann-Morgenstern [5], in which economists searched for inconsistencies and inconsistencies in expected human behaviour.

Due to careful study of models of expected utility and subjective expected utility described by L. Savage, famous paradoxes of M. Allais [6] and D. Ellsberg [7] were discovered. These paradoxes illustrated the existence of a large number of inconsistencies and abnormal facts in the economic behaviour of individuals that could not be explained from the positions of the existing theory. The works of authors such as M. Allais (1953), G. Markowitz (1952), D. Ellsberg (1961) [6-8] were the first step to change the dominant representations of classical economic theory, theory of expected utility and theory of subjective expected utility.

The second stage is the stage of the emergence of the behavioural economics (1955-1974). This stage is associated with the influence of "A dynamic theory of personality" by K. Lewin [9] on economic models, in particular his concept of the "level of claims" of the individual. This stage is characterized by a deliberate refusal of a number of the provisions of classical economy and the formation of significant scientific schools: 1) a school of Carnegie Mellon University, which investigated behaviour of companies in markets, 2) a Michigan school, which concentrated its attention on the behaviour of consumers. The behavioural theory of the firm (the school of the University of Mellon-Carnegie) is associated with the name of G. Simon [10]. Carrying out empirical work with factors and uncertainties, he managed to develop and substantiate the theory of "limited rationality", which explained: why firms and other organizations are taking an unrealistic but satisfactory solution; as well as subjects (in conditions of insufficient information) tend not to maximize utility but to obtain satisfaction [10].

Further investigation of these issues has significantly expanded the set of empirical paradoxes, theoretical interpretation of which lies in the work of R. Cyert and J. March "A Behavioural Theory of the Firm" (1963) [11]. This book is still considered relevant and highly important in the framework of the behavioural economics.

In subsequent years, the theory of bounded rationality was further developed in theories, where uncertainty was interpreted not as the degree of accessibility of information, but as individual human abilities and their comprehension. One of the significant theories of this period was the theory of the X-efficiency of Harvard University Professor Harvey Leibenstein [12]. In this theory a degree of rationality of an economic subject was treated not as a constant fixed value, but as a variable: a person, depending on the specific circumstances or context of the situation, be- haves with different degrees of rationality. Significant contributions were made at this stage by scientists such as R. Thaler, R. Selten and others whose works allowed forming a set of actual experimental data characterizing the shortcomings of classical theories.

Behavioural theory of consumption (the Michigan school) explores mainly the behaviour of consumers. Its main theoretical concepts are formulated in the works of American economist G. Katona [3]. He described the division of consumer spending and savings into mandatory and optional. Subjective factors influence the main, non-mandatory types of purchases and savings more than objective ones.

Thus, at this stage, there was a fundamental rejection of the classical axioms patterns of economic theory, which opened wide opportunities for the formation of behavioural economics.

The third stage (1974-1990) is the stage of scientific formation and it was associated with the penetration of cognitive psychology (from Latin cognitio "knowledge, cognition") into the economic theory and mathematical psychology. Since the late 1960s articles of P. Slovik, D. Kahneman and A. Tversky [13] began to publish. In 1979 the main work "Prospect Theory: An Analysis of Decision under Risk" (D. Kahneman and A. Tversky) was published [14], the main provisions of which were considered from the standpoint of cognitive psychology. Several attempts were made to explain the existing deviations in the expected behaviour of people in rational and irrational economic decision-making process.

Authors presented a large number of results empirical studies, during which people were asked to make a choice between different alternatives. It was convincingly shown that most people cannot rationally estimate the magnitude and probability of the expected benefits or losses.

(a) The reaction to equivalent situations depends on the expected gain or loss. This phenomenon is called asymmetric response to changes in well-being (the person is more afraid of losing, i.e. emotions of losses and gains are asymmetric).

(b) Most people do not have an objective assessment of the probability of certain events.

From these theoretical positions an independent scientific field of research has emerged and it got the name of behavioural economics. This term is quite understandable from the standpoint of the semantic analysis of each concept created by the construct: "behaviour" and "economics". Behaviour is a combination of actions of a person (or group), which are stable in a certain period of time. Economics is "the art of housekeeping" (or farming company, region, and country). In this case, "behavioural economics" is a theory describing the actions of a person (or a group of people) in different conditions of farming (from personal to state).

At this stage, the methods of behavioural economics were used to explain situations of intertemporal choice. Thus, American scientist G. Ainsley dis- 
covered the psychological method of "hyperbolic discounting", which became the opposite of the exponential discounting used in traditional models [15].

The fourth stage (1990-2000) is the stage of development, which was associated with the application of mathematical tools of game theory in economic theory, in particular, in sections that explain the strategic interaction of economic agents at different levels and in different conditions, and also their desire to find the best solution to the conflict that has appeared.

It should be noted that the developed concepts of analysis have become generally accepted as independent trends in the theory of games:

- an analysis of equilibrium in the theory of noncooperative games by J. Nash;

- Shapley value - a vector distribution of the optimality of the winning by L. Shapley;

- a procedure of tracing by J. Harsanyi and R. Selten.

These instruments explain the real behavior of the participants and make it possible to predict the results and specific consequences of certain actions.

One of the most significant and discussed results in the behavioural game theory is the theory of social preferences and fair distribution. "An ultimatum game" most vividly demonstrates this theory. Authors of this article believe it is appropriate to note that the first empirical works with its use were carried out by V. Gut, R. Schmittberger and B. Schwarz in 1982. At the beginning of the XXI century, the research was continued and the findings made it possible to prove that the rational behaviour of a person is demonstrated by the person in the case of a balance between cognitive and emotional decision-making mechanism.

The fifth stage (2001 to the present) is the stage of expansion. It is associated with the penetration of the results of studies of such sciences as psychophysiology, neurophysiology, and neurobiology into the economic theory, which led to the emergence of a new vector of development of the behavioral economics neuroeconomics.

The basic model was the model of making perceptual decisions, developed by M. Chadlen and W. Newsome [16]. This model is based on the analysis of the behavior of monkeys. Subsequently, studies of the influence of hormones on social and economic interaction were held by P. Zak in 2001 [17]; the role of emotions in decision-making (A. Beshar and A. Damasio) was also analyzed [18]. And studies on the coding of the subjective value of the decision gave rise to the emergence of "neuromarketing" (E. Smidts) [19]; research using MRI and computed tomography of various thought processes from the standpoint of external management gave rise to" neuromanagement" (J. Charles) [20].

Another direction in the expansion of the behavioral economics by new theories is the research of human behavior work. Within the framework of this direction, a team of scientists from the South Ural
State University (National Research University) develops features of rational and irrational behavior of a person in the process of performing professional functions. Moreover, there is a great range of questions, which interested for many scientists and the work upon them has already begun:

- questions of measurement in social and humanitarian studies (A.L. Shestakov and A.V. Keller);

- a search for new mechanisms to increase labor productivity (I.P. Savelyeva, I.V. Rezanovich, E.A. Rezanovich and I.M. Tsalo);

- determination of the degree of influence of the state of stress on human labor behavior (V.E. Tseylikman, O.B. Tseylikman, M.S. Lapshin);

- new mathematical models for the assessment of professional competencies are being developed (A.V. Keller, I.V. Rezanovich).

The first results were approved by the scientific community.

\section{Conclusion}

Thus, behavioral economics studies a variety of patterns of behavior of consumers, firms and human labor, referring to a variety of psychological, psychophysiological and neurophysiological phenomena that have no place in a rational economy. The use of new models in business will help enterprises to be more sustainable, and the management of personnel to become more efficient.

\section{References}

1. Tarde G. Psychologie economique. Collection: Bibliotheque de philosophie contemporaine. Ancienne Librairie Germer Bailliere et Cie, 1902.

2. Garai L. To the psychology of economic rationality. In: Understanding economic behaviour. 12th Annual Colloquium of IAREP, the International Association for Research in Economic Psychology. Handelshoejskolen I Aarhus, 1987, pp. 29-41.

3. Katona G. Psychological Analysis of Economic Behaviour. NY, McGrow-Hill, 1951.

4. Fisher I. Mathematical Investigations in the Theory of Value and Prices. Connecticut Academy of Arts and Sciences, 1892. $124 \mathrm{p}$.

5. Neumann J., Morgenstern O. Theory of Games and Economic Behaviour. Princeton University Press, 1944. DOI: $10.2307 / 2572550$

6. Allais M. Le Comportement de l'Homme Rationnel devant le Risque, Critique des Postulatset Axiomes de l'Ecole Americaine. Econometrica, 1953, vol. 21. DOI: 10.2307/1907921

7. Ellsberg D. Risk, Ambiguity, and the Savage Axioms. The Quarterly Journal of Economics, 1961, vol. 75 (4), pp. 643-669. DOI: 10.2307/1884324

8. Markowitz H. The Utility of Wealth. The Journal of Political Economy, 1952, vol. 60 (2), pp. 151158. DOI: $10.1086 / 257177$

9. Lewin K. A Dynamic Theory of Personality. New York - London, McGraw-Hill Book Company Inc., 1935. 


\title{
Экономическая теория и мировая экономика
}

10. Simon A. Administrative Behaviour. A Study of Decision-Making Processes in Administrative Organization. 3nd ed. London, UK, The Free Press, Collier Macmillan Publishers, 1976.

11. Cyert R., March J. A Behavioural Theory of the Firm. 2nd ed. Wiley-Blackwell, 1992. 268 p.

12. Leibenstein H. Allocative Efficiency vs. "XEfficiency". The American Economic Review, 1966, vol. LVI.

13. Slovic P., Lichtenstein S. The Relative importance of probabilities and payoffs in risk-taking. Journal of Experimental Psychology, 1968, vol. 78(3), pt. 2, pp. 1-18. DOI: $10.1037 /$ h0026468

14. Tversky A., Kahneman D. Judgment under uncertainty: Heuristics and biases. Science, 1974, vol. 185 , no. 4157 , pp. $1124-1131$. DOI: $10.1126 /$ science. 185.4157.1124

15. Ainslie G. Impulse control in pigeons. Journal of the Experimental Analysis of Behaviour, 1974, vol. 21 (3), pp. 485-489.

16. Chadlen M., Newsome W. Neural basis of a perceptual decision in the parietal cortex (area LIP) of the rhesus monkey. Neurophysiology, 2001, vol. 86 (4), pp. 1916-1936. DOI: 10.1152/jn.2001.86.4.1916

17. Zak P., Kurzban R., Matzner W. The Neurobiology of Trust. Annals of the New York Academy of Sciences, 2004, vol. 1032, pp. 224-227. DOI: 10.1196/annals. 1314.025

18. Beshar A., Damasio A., Tranel D., Deciding advantageously before knowing the advantageous strategy. Science, 1997, vol. 275, iss. 5304, pp. 12931295. DOI: $10.1126 /$ science.275.5304.1293

19. Smidts A. Kijken in Het Brein: Over De Mogelijkheden Van Neuromarketing, 2002.

20. Charles J. Management Rewired: Why Feedback Doesn't Work and Other Surprising Lessons from the Latest Brain Science. Penguin Group, 2009.

Irina V. Rezanovich, doctor of pedagogical sciences, professor, head of the department "Labor Economics and Personnel Management”, South Ural State University (Chelyabinsk), rezanovichiv@susu.ru

Evgeniy A.Rezanovich, candidate of economic sciences, associate professor of the department "Labor Economics and Personnel Management", South Ural State University (Chelyabinsk), rezanovichea@susu.ru

Alevtina V. Keller, Doctor of Physical and Mathematical Sciences, Director of the Institute of Natural and Exact Sciences, South Ural State University (Chelyabinsk), kellerav@susu.ru

Irina P. Savelieva, Doctor of Economics, Director of the Higher School of Economics and Management, South Ural State University (Chelyabinsk), savelevaip@susu.ru

Received February 12, 2018

Удк 330.8

DOI: $10.14529 / \mathrm{em} 180103$

\section{ЭВОЛЮЦИЯ ПОВЕДЕНЧЕСКОЙ ЭКОНОМИЧЕСКОЙ ТЕОРИИ}

\author{
И.В. Резанович, Е.А. Резанович, А.В. Келлер, И.П. Савельева \\ Южно-Уральский государственный университет, г. Челябинск, Россия
}

\begin{abstract}
Появление Поведенческой экономики связано со стремлением экономической теории найти объяснение имеющимся в практике парадоксам, которые не могут быть прояснены с позиций классической экономики. С этой целью стали использовать достижения других наук и, прежде всего, психологии. В статье прослеживается генезис поведенческой экономики, обоснован критерий для выделения этапов ее эволюционирования. Сделанная периодизация позволила определить влияние появляющихся теорий на развитие экономической мысли. В частности, первый (пропедевтический) этап, тесно связанный с экономической психологией, позволил анализировать с психологических позиций теории ожидаемой полезности и теории субъективной ожидаемой полезности, раскрывая аномальные факты в экономическом поведении индивидов. Второй этап (зарождение поведенческой экономики) тесно сплетено с «Динамической теории личности» К. Левина. Именно на этом этапе сформировались фундаментальные научные школы: школа Университета Меллона-Карнеги, исследующая поведение фирмы на рынке, и Мичиганская школа, сосредоточившая свое внимание на поведении потребителей. Третий этап (становления поведенческой экономики) интегрирует экономическую теорию с когнитивной психологией и математической психологией, благодаря чему были даны объяснения поведению
\end{abstract}


людей при рациональном и иррациональном принятии экономических решений. Четвертый этап (развитие поведенческой экономики) связывается с применением математического инструментария теории игр в экономической теории, в частности в разделах, которые объясняют стратегическое взаимодействие экономических агентов на разных уровнях и в различных условиях. Пятый этап (расширение поведенческой экономики) обусловлен влиянием достижений в психофизиологии, нейрофизиологии, нейробиологии, что дало возможность появлению нового направления в поведенческой экономики - нейроэкономики. Отмечены успехи в исследовании поведения человека труда группой ученых из Южно-Уральского государственного университета, открывающие новые перспективные возможности в развитии Поведенческой экономики.

Ключевые слова: поведенческая экономика, экономическая психология, когнитивная психология, математическая психология, математическая теория игр, этапы развития поведенческой экономики, научные школы, нейроэкономика, нейроменеджмент, современные перспективные направления исследований поведенческой экономики.

Резанович Ирина Викторовна, доктор педагогических наук, профессор, заведующий кафедрой «Экономика труда и управление персоналом», Южно-Уральский государственный университет (г. Челябинск), rezanovichiv@susu.ru

Резанович Евгений Анатольевич, кандидат экономических наук, доцент кафедры «Экономика труда и управление персоналом», Южно-Уральский государственный университет (г. Челябинск), rezanovichea@susu.ru

Келлер Алевтина Викторовна, доктор физико-математических наук, директор института естественных и точных наук, Южно-Уральский государственный университет (г. Челябинск), kellerav@susu.ru

Савельева Ирина Петровна, доктор экономических наук, директор высшей школы экономики и управления, Южно-Уральский государственный университет (г. Челябинск), savelevaip@susu.ru

Поступила в редакцию 12 февраля 2018 г.

\section{ОБРАЗЕЦ ЦИТИРОВАНИЯ}

Evolution of Behavioral Economic Theory / I. Rezanovich, E. Rezanovich, A. Keller, I. Savelyeva // Bectник ЮУрГУ. Серия «Экономика и менеджмент». 2018. - T. 12, № 1. - C. 23-27. DOI: 10.14529/em180103

\section{FOR CITATION}

Rezanovich I., Rezanovich E., Keller A., Savelyeva I. Evolution of Behavioral Economic Theory. Bulletin of the South Ural State University. Ser. Economics and Management, 2018, vol. 12, no. 1, pp. 23-27. DOI: $10.14529 / \mathrm{em} 180103$ 